\title{
9. Saltwater Placenames around Mer in the Torres Strait
}

\author{
Nick Piper
}

\section{Introduction}

This paper explores the names and meanings given for some of the reefs and cays (small low-lying islands) around Mer, Dauar and Waier (known as the Murray Islands) in the Torres Strait. ${ }^{1}$ Such placenames 'tell us something not only about the structure and content of the physical environment itself but also how people perceive, conceptualize, classify and utilize that environment' (Thornton 1997: 209). They therefore 'intersect three fundamental domains of cultural analysis: language, thought and the environment' (1997: 209). The aims of this paper are to bring to light naming patterns for places around Mer. It is hoped that such a focus on saltwater placenames will prompt other researchers to document this knowledge as a potential resource for sea claims. ${ }^{2}$

The paper is organised as follows: the first section looks at different sources for placenames in other parts of the world. The second section introduces the reader to the Torres Strait region and its languages, in particular the languages of the eastern islands. The third section focuses on the names for saltwater places around Mer, their lexical source, grammatical structure and in some cases, the choice of language.

\section{Sources for placenames}

In North America, interest in Indigenous placenames was raised by an American anthropologist, Franz Boas, who worked with Inuits around Baffin Island (Thornton 1997: 211). Since 2000, a large project has aimed at further documenting Inuit placenames, specifically those of the Sikusilarmiut (Henshaw

\footnotetext{
1 My thanks to the following people for their comments and suggestions: Dana Chahal, Penny Johnson, Rachel Nordlinger, Colin Scott, Anna Shnukal, Jane Simpson and Felix Ameka. I also thank the two reviewers for their insightful comments. My gratitude to Garrick Hitchcock for helping me with the maps. A special thanks to the Mer community, in particular Usiam and Atai Wailu, both now deceased, as well as Alo and Terry Tapim, Simeon and Adimabo Noah, Mabigi Tabo, Dalton Cowley and Palen Passi.

2 For example, the case of Leo Akiba and George Mye on behalf of the Torres Strait Islanders of the Regional Seas Claim Area and the State of Queensland and others, filed in the Federal Court of Australia in November 2001 and determined by the High Court on 7 August 2013.
} 
2006). This study, based on 420 placenames, found that people's discussions about places revolved around a number of recurrent themes listed below (i)(vii) (2006: 56). Furthermore, the researchers found that certain themes, such as topography, were more common than others, such as harvesting activities. On this basis, they constructed a typology of salient features for Sikusilarmiut people when talking about place:

(i) topographic features such as mountains, cliffs and peninsulas;

(ii) descriptive features based on animals, plants, and animal behaviour;

(iii) climate sensitive features such as seasonal camping areas, sea ice, ocean currents, snow conditions, temperature conditions and wind direction, animal migrations and nesting areas;

(iv) metaphorical features based on animals or humans or mythical associations;

(v) historic events;

(vi) travel routes and camp sites;

(vii) harvesting activities such as hunting, processing and caching areas.

The typology identifies themes or features most commonly associated with places. The environment dominates through its landscape, plants, animals, seasonal accessibility and associated mythology. ${ }^{3}$

In the Marquesas Islands in French Polynesia, a study on landscape terms shows an overlap between the themes associated with Sikusilarmiut places and the categories used for naming Marquesan places (Cablitz 2008: 209):

(i) topographic features such as Tepapa 'the lava rock';

(ii) descriptive features of plants or animals such as Fafa'ua 'manta ray';

(iii) metaphorical features such as body part terms as in Te'uma 'the breast';

(iv) mythological figures such as Teohootupa 'the cape of Tupa';

(v) objects or things such as Ke'atu'ipopoi 'poipoi (Citrifolia morinda) pounder' or Popoma $\bar{a}$ ' fermented breadfruit ball'.

Placenames can also combine several semantic categories. For example, Matafenua 'land's end' means literally: eye land, combining a topographical feature with a body part. Grammatically, the placenames can be a single noun,

3 Only one mythological example is provided. A place called Iqsauti, literally 'side of a face', which evokes a story about an illicit love affair. 
a complex noun phrase such as 'Otopuhi 'moray's hole' (literally: inside moray) or a descriptive phrase which can be expanded to include events or states such as Tutaekena 'Kena defecates'.

Australian Indigenous naming patterns vary across the country depending on the society and environment (Hercus and Simpson 2002: 2). In their introduction, Hercus and Simpson (2002: 19) provide a summary of common semantic categories found for central and southern placenames (exemplified with Warumungu, a language spoken in Central Australia):

(i) topographic names which describe the land and/or environment such as Karlukarlu 'boulders';

(ii) incidents or events connected to a mythological figure or Ancestral Being such as Karnkka 'moon' or Ngurru pakinyi '(someone) pierced a nose';

(iii) names which evoke a mythological figure and a descriptive feature at the same time. The names may be literal such as Kijjiparraji, 'white ghostgums', where ancestral Mungamunga women turned into white ghostgums, or metaphorical such as Parakujurr 'two body entrances', which marks the place of two rockholes.

While these naming patterns may be common for Australia, they are not universal. Some of the variations include placenames which overtly name an ancestor such as the Ngalakgan place Ganjarri 'bonefish' (Baker 2002: 109) or those which can have a generic topographic term included such as the Wik places Wayingk Thiikanen 'Wayingk Island' and Merrek Ngamp 'Merrek River' (Sutton 2002: 82) or the Yir-Yorront name for a land-tract Larr-Low+Pannan 'Crying place' with the noun larr 'place' (Alpher 2002: 134).

In terms of their grammatical structure, Australian Indigenous placenames can be a simple noun or complex noun phrase (such as the examples given above), a verb or verb phrase or headless relative clause. Thus, the Arabana people call Mount Arthur, Pakalta 'he is digging for someone else', and the site of a water bore, Wabma tharkarnayangu '(where) the Snakes stood up' (Hercus and Simpson 2002: 20).

In summary, common semantic features for naming places emerge: environmental such as topography, plants, animals and mythology. These features may be expressed literally or metaphorically. In terms of their grammatical structure, placenames may be expressed by single words, complex phrases or clauses. Some of these patterns and structures are also found with saltwater placenames in Meriam, a language of the Torres Strait (sections 5 to 11). 


\section{Torres Strait}

The Torres Strait is the stretch of water between Australia and Papua New Guinea (see Map 1). It is dotted with over 100 islands, 15 of which are permanently inhabited. To the east of the Strait lies the Coral Sea and to the west, the Arafura Sea. The waters have countless coral reefs which abound in natural resources. Torres Strait Islanders' lives revolve around the sea and they rely on it for their daily diet, or at least to supplement it. They catch fish on the foreshore using lines or nets, forage at low tide or travel by dinghy to fish, dive and hunt sea creatures such as turtle or dugong. Their life at sea is celebrated through their songs and dances. Their identity is connected to the sea and this is evidenced by their marine totems which are, amongst others, dolphins, whales, turtles and fish.

Linguistically, the Torres Strait is at the intersection of two large language regions, Papuan and Australian. The eastern islands language is related to Papuan languages from the Eastern Trans-Fly River family (Alpher et al. 2008: 15). The western and central Islands language and its dialects are related to Australian Pama-Nyungan languages (2008: 28).

\section{Meriam language}

The original language spoken in the eastern Torres Strait is Meriam or Meriam Mir (MM), literally 'Meriam language'. Like many Papuan languages, it is a verb final language (S-O-V) with agglutinating morphology. Nominals are casemarked to show their syntactic role and there is a regular process of nominal compounding, typically in a modifier-head relationship. Verbs cross-reference core arguments of the sentence and carry information for person, number, tense and mood. Number distinctions are singular, dual, paucal and plural, which are marked syntactically and through verb root forms. Although Meriam was originally spoken throughout the eastern islands, nowadays, the majority speak the regional creole, Torres Strait Creole (TSC) as their first language.

Topographical marine terms are often given in the creole rather than in Meriam. Sandbars or cays are called sanba (TSC) rather than wésor ${ }^{4}$ (MM), literally 'sand back'; small sunken reefs are referred to as spot (TSC) 'small sunken reef' rather than kep (MM), literally 'seed, spot, small sunken reef'; a lagoon is usually called lagun (TSC) rather than keper 'a pool', siridsirid (MM) 'a shallow lagoon' or ubir (MM) 'a deep lagoon' and channels are called pasis (TSC) rather than kes

4 I am using Meriam orthography with the addition of accents. Stress is contrastive although typically, the second syllable is stressed. When the pattern diverges from this, the stressed syllable is overtly marked with an accent. 
(MM) 'channel' or karem (MM) 'deep sea or deep channel'. However, Eastern Islanders tend to talk about their reefs as nor (MM) rather than rip (TSC) 'reef' so that the Barrier Reef is called Baria or Op Nor (MM).

\section{Meriam saltwater placenames}

This study is based on the saltwater placenames around Mer, Dauar and Waier (see Maps 2 and 3). ${ }^{5}$ The following categories are sources for naming: i) descriptive, ii) ancestral, iii) narrative and iv) miscellaneous for those placenames of unknown origin (see List of placenames). Most places are named after the personal name of an ancestor. The next largest group of places are named after a physical or descriptive feature such as the marine or bird life, habitat, physical properties or location. Only a few places are named after an event. In addition, there are placenames associated with several semantic categories as their name is a combination of a descriptive feature and ancestral name, or the ancestral name itself is descriptive. Furthermore, some places have alternate names that relate to a different semantic category.

\section{Descriptive names}

Reefs can have descriptive names drawn from one or more of the following features:

- marine life and habitat

- bird life and habitat

- physical properties such as size, shape or matter

- relative location/direction

While most descriptive names are given with a literal meaning, those which describe the shape of a reef are given metaphorically.

\subsection{Marine life and habitat}

There are reefs named after fish. Bologor Kep (kep 'small sunken reef') is named after the sawfish and Pakor reef is named after the red bass fish. ${ }^{6}$ Two personal ancestral names, Au Siar and Kebi Siar, mean literally 'Big Cod' and 'Little Cod'

5 Variations between places on the map and my own references are due to different spelling and some places referred to in my paper are not marked on the map.

6 There is one reef which has the public name of a type of fish but it is a permutation of an ancestor's name. It is kept secret because it marks the spot where the ancestor was killed by sorcery. In this instance, the name is not associated with the prevalence of a fish but used because of a taboo placed on the real name. 
(see section 7 for a discussion on ancestral names). There is one reef, Adud Nor, named literally: Bad Reef because it had no fish. Although the reef now has coral and hence fish, it has retained its original name. ${ }^{7}$ There are surprisingly few reefs named after fish considering Meriam people's extensive knowledge and dependence on marine resources. This may be that good fishing spots are regarded as private information and thus kept secret from other fishermen. Alternatively, it may be that fish are not so localised. ${ }^{8}$

Reefs are also named after other marine creatures. Thus, Nazir Bed is the name of a reef based on nazir (MM) 'trochus shell' and bed (TSC) 'bed or layer'. ${ }^{9}$ The use of a TSC word suggests a newly coined name. It was probably renamed in the early 20th century when the Torres Strait had a thriving trochus shell industry and these were collected for making buttons. ${ }^{10}$ According to one Meriam, it was made into a communal area in his father's time and profits from the shell sales were pooled for the benefit of the whole community. ${ }^{11}$

While the previous placenames are based on marine life, they can also be named after habitat. There is a point on one of the reefs called Wazar which is possibly related to the Meriam word zar 'the place where fish go to hide and rest' (it also refers to a type of garden plot) and is found in the Meriam idiom: lar waikwereder taba zarge 'The fish stay in their place'. ${ }^{12}$

\subsection{Bird life and habitat}

Reefs are also named after bird life. Serar reef is named after the tern (MM). Tolitoli Nor (nor 'reef') is named after the sandpiper, toli (MM). Birds' habitat can also be a source for naming. Raine Island, which is south of Mer and known to Meriam people through their sea travels, is called Ebur bub werwer kaur, literally: 'bird chest eggs island', because birds go there to nest and keep their eggs warm by covering them with their chests. ${ }^{13}$

\subsection{Physical properties or relative location/direction}

The physical dimension of the reef can be incorporated into its name. Adjectives such as au 'big' and kebi 'little' indicate the reef's relative size: Au Meiri and

\footnotetext{
7 Atai Wailu, pers. comm.

8 I am grateful to an anonymous reviewer for suggesting this second possibility.

9 I am assuming that the word has been borrowed from TSC rather than English although there may have been a local English at the time.

10 No-one can recall its former name.

11 Alo Tapim, pers. comm.

12 Alo Tapim, pers. comm.

13 Colin Scott (email 19 October 2009) was also given the alternate names: Eburira Ged 'bird-poss place', Sub Kaur 'foreign island' and Maizab Kaur which is also the name for Bramble Cay near Erub.
} 
Kebi Meiri (Meiri - personal name of ancestor), Au Siar and Kebi Siar (Siar personal name of ancestor), Au Karmeri and Kebi Karmeri (Karmeri - personal name of ancestor), Au Bomi Nor and Kebi Bomi Nor (bomi - from TSC bomi 'bommie or bombora'). ${ }^{14}$

The relative location of a place can also be a source for naming. Two reefs called by the personal names of ancestors, Madir and Marirar, have alternative names identifying their relative location. Madir is also known as Mer Au Nor, literally: Mer Big Reef, because it is closer to Mer, and Marirar is also known as Sanba Au Nor, literally: Sanba (TSC) Big Reef, because it is closer to the sandbar, Kérged.

The name for the Barrier Reef itself, Op Nor, provides information about its direction and spatial orientation. $O p$, which is the personal name of an ancestor, also means front, face, upper or outside. Thus, Op Nor is the reef that faces directly into the southeasterly wind sager, an important wind in the Torres Strait. ${ }^{15}$

Placenames can also incorporate the names of objects which resemble the shape of the reef. In some instances, they are part of the name whilst in others, they are the name for the reef itself. As such, it is not a literal use of the name but a metaphorical use drawn from the similarity between object and reef. For example, the long, narrow shape of a handle is extended in meaning to refer to the shape of a reef: Giau+lit (Giau - personal name of an ancestor+handle), Wabi+lit (personal name of ancestor+handle) and possibly, Tu+lit ( Tu unknown origin +handle).

Other objects which are a source for placenames, include the leaves, roots and seeds of plants. For example, $A p$ is a reef named after the Macaranga shrub because its leaves are similar in shape to the outline of the reef. Other reefs named after plants are: Sim Kep, named after the hibiscus tree, and Girwai, named after the wild yam because it is round with roots growing away similar to that reef. Sirib ${ }^{16}$ reef may also be related to the vine bearing the same name. The generic term for a small sunken reef kep is related to the word for a seed and hence, metaphorically extended in meaning to include small, sunken reefs.

Body parts can be a source for reefs' names because of their shape. The reef Pokopoko is named after the top of the turtle's intestines: pokopoko teibur because it twists around like a turtle's intestines. The reef Ped, which is the personal name of an ancestor, means literally 'bald'. Its appearance is similar to a bald man's patch as it has an outer circle and a solid coral mass in its centre. It is not named this way because of scarce resources.

14 My thanks to Anna Shnukal for pointing out its source.

15 Alo Tapim (pers. comm.)

16 My thanks to Anna Shnukal for pointing out the correct pronunciation. 


\subsection{Ecology or topography}

Reefs are also named after their geological matter. Thus, the reef Bur is named after the MM word for saltwater mud from the adjective burbur, and Akesakes reef derives its name from the verb dikes meaning 'break into pieces' as the reef is large chunks of cracked and broken coral. Another reef Zor ${ }^{17}$ means literally pumice stone. The reef Wewe Mebgor, shortened to Mebgor, is formed with the adjective wewe meaning 'sandy' and Mebgor, the personal name of an ancestor. A stretch of the Barrier Reef called Garargarar Op Nor is derived from the noun garar meaning 'raised rocky platform'.

Generic topographic features may also co-occur with a placename. In some cases, it has become an integral part of the name and in other cases, it is optional. For example, the Barrier reef is always called op Nor and omission of the word nor yields a different meaning:

\section{(1) Ka nabakiamulu Op Norem.}

I'm going to the Barrier Reef.

$\begin{array}{lll}\text { ka } & \text { na-bakiamu-lu } & \text { Opnor-em }^{\text {A }} \\ \text { 1.SG.S } & \text { FUT.1-go-FUT.1.SG } & \text { Place-ALL }\end{array}$

(2) Ka nabakiamulu opem.

I'm going to the front.

Note A: The following conventions are used for glossing in all examples: SG: singular; PL: plural; 1: first person; 3: third person; S: subject; PERF: perfective; FUT: future; INTR: intransiviser; NOM: nominaliser; $\mathrm{O}$ : accusative case; LOC: locative case; ALL: allative case.

In other instances, the topographic feature does not have to be overt, which suggests that it is not part of the placename. For example, when talking about the reef $\mathrm{Wad}$, named after the personal name of an ancestor, the speaker can say:

\section{(3) Ka nabakiamulu Wadem/Wad norem.}

I'm going to Wad reef.

ka nabakiamulu

1.SG.S FUT.1-go-FUT.1SG

Wadem/Wad norem.

Place-ALL/Place reef-ALL

A topographic feature may also be used to identify a specific place within a place. For example, the reef Eur, named after an ancestor, has a passage through it called Eur Kes 'Eur passage'. A topographic feature may also be used to disambiguate between two places. The small reef close to the landsite $E d$ is usually called Ed Kep to disambiguate it from the landsite with that name.

17 It may actually be a stretch of reef. 


\section{Ancestral names}

The most common source for the names of reefs are ancestors; that is, the places are named after the personal name of an ancestor, not what the ancestor did in that place. This contrasts with Australian Aboriginal placenames where the name generally evokes an incident or event associated with the Ancestral Being.

Around half of these personal ancestral names in Meriam have no literal meaning or the meanings have been lost.These include: Aum, Asmet, Birig, Eur, Gaidan, Giau, Karas, Karmeri, Keud, Madir, Marirar, Meme, Mer, Merad, Neiri, Or, Sagore, Sarek, Seu, Simu or Smu, Soswared, Tobag, and Wad.

A few of these personal ancestral names combine with a meaningful word. (These have already been discussed). They include: Giau+lit (Giau+handle), Au/ Kebi Meiri (big/little Meiri), ${ }^{18} \mathrm{Tu}+$ lit (Tu+handle) and Wabi+lit (Wabi+handle). There is another ancestral placename, Seutam, which is derived from the ancestral name, Seu, and the word for the branch of a tree: tam. The ancestors, Seu and Seutam, were in a mother-daughter relationship. The use of the word 'branch' in the daughter's name signals through metaphor the relationship between parent and offspring.

Other ancestral placenames also have a literal meaning (some of which have already been discussed in earlier sections):

Girigiri 'bird of paradise'

Kérged 'ovary+place'?

Koki 'northwest wind'

$O p$ 'front, face, upper or outside'

Ped 'bald'

Sam Karem 'cassowary'

Seibri 'crocodile',

Sepgiz 'earth+root'

Serar 'tern'

Siar 'cod'

18 These reefs are sometimes called in TSC Big Mary and Little Mary but Meriam speakers say that the ancestral name is Meiri. 
Indigenous and Minority Placenames

Wai 'sprouting coconut'19

Wewe Mebgor 'sandy moon+saltwater?' (gor an earlier form of gur 'saltwater'?) or from 'sandy moon+slope'. ${ }^{20}$

There is a myth which details how reefs to the north of Mer came to be named: ${ }^{21}$ There were ten brothers and one sister. While the brothers were building fences to stop thieves from entering, their sister, Kérged, would visit her girlfriends and speak ill of her brothers. When the eldest brother, Limaranda, heard about it, he got very angry. As Meriam law forbids gossip, he ordered his brothers to kill her and her girlfriends. The brothers took the girls and threw them into the water. These are the reefs named after the girlfriends: Op, Aum, Kebi Meiri and Au Meiri, Birig, Or, Wabilit, Giaulit, Tulit, Garboi, Merad, Au Siar and Kebi Siar, Koki and Wad. The brothers were too upset to throw their sister into the water so Beizam, the eldest in the group, took her and laid her down on the sandcay, Kérged. When Limaranda saw their actions, he banished his brothers from the island. The following reefs are named after them: Marirar, Meme, Sarek, Gaidan, Madir, Karas and Ped. Their physical proximity replicates the blood ties of the ancestral brothers.

\section{Narrative names}

There are a few reefs whose names evoke an incident, mishap or event that occurred at the place and as such, they can be categorised as narrative. These are not restricted to ancestral events and in fact, seem to indicate relatively recent origin given that some of the names are in TSC, which only arose in the late 1800's (Shnukal 1988: 5). The main protagonist(s) or an object associated with the event may be the source for the name.

For example, the reef Ped is also known as Muma Kep, ${ }^{22}$ the name of the dinghy that nearly sank when it was overloaded with trochus shells. Similarly, Digi Kep (TSC) is named after a dinghy which sank at the place. Nazir Bed may also belong to this category with a name shift occuring when people started collecting trochus shell for payment.

In some cases, the person or people involved with the event have become the name for the place. For example, Mesnare Nor (TSC) was coined after the first

\footnotetext{
19 Ricardo Idagi, pers. comm.

20 Anna Shnukal (pers.comm.).

21 The story was told by Usiam Wailu to Colin Scott in English in August 2001 and told to me in Meriam in September 2006.

22 I have not investigated the use of alternate names in discourse or whether there are differences in register. This awaits further study.
} 
missionaries spent a night there on their way to Erub (Darnley Island) in July 1871. ${ }^{23}$ Napolan Kep is named after the man who was killed in that spot by sorcery when a shark ate him. ${ }^{24}$ Bologor Kep is also known as Zozi Spot because a man called George/Zozi (TSC) was diving for trochus and mistook a bird for a big shark so swam back at full speed to his dinghy!

The coexistence of several names for reefs and/or the replacement of names with another name demonstrates the ongoing relationship between the people and their waters; that is, Meriam people continue to travel, hunt, dive and fish in these waters. When significant events occur, they are recounted back to family on Mer. The association of the person or thing to the place becomes the name for the place itself.

\section{Miscellaneous names}

There are a number of placenames whose origins are unknown. People cannot remember the reasons or circumstances for such names. Some possible lexical sources for the more opaque names have been provided:

Arbori Kep - possibly derived from the nominalised form of the verb: darborik 'to aim and miss' or barbor 'to stand out or be prominantly visible'25

Au/Kebi Dudum 'big/little speed'

Bau Kep - possibly from the word bau 'seat' because of its shape or from a personal name

Dingi New Pas (TSC) 'Dinghy New Patch' - an alternative name to Sepgiz, the personal name of an ancestor

Wamkem - derived from the reduced form of bisiwam 'a type of grass skirt' and kem 'with'26

Werer 'Hunger' - possibly coined when someone became stranded and hungry or to identify it as hazardous and 'hungry' for dinghies ${ }^{27}$

Zer Kep 'banana skin' - possibly based on its shape or from resource depletion and stemming from the idiom: No kaba zer eme abi (literally: just banana skin hang fell) 'I have passed on all that I know'.

\footnotetext{
23 No-one can remember its former name.

24 Usiam Wailu (pers. comm.)

25 Alo Tapim (pers. comm.), has heard the place called Arborarbor Kep.

26 Alo Tapim (pers. comm.), believes it is associated with the women from Dauar island.

27 This was suggested by Jane Simpson (pers. comm.).
} 


\section{Coreferential names}

There are a few reefs whose names coincide with the names of landsites or fishtraps. In some cases, these reefs are a short distance from the landsite bearing that name. It is conceivable that the name designates an area which includes both land and sea, or that the name for the landsite is extended seaward to include the reef. Thus, the reef Karmeri is a short distance from the site on Dauar island with that name. Likewise, Ed Kep is a small, sunken reef close to the landsite $E d$ on Mer.

There are, however, other reefs which are distant from the landsite or fishtrap with which it shares its name. For example, Birig reef is far from the landsite with that name and Giau reef is also some distance from the fishtrap with the same name. In such instances, one cannot argue that the shared name is based on proximal distance. Nonetheless, these places must be connected in some way. When Meriam people were asked about these, they could not provide an explanation. Whatever the connections, these have been forgotten.

There are, of course, examples of water sites in other areas which share a name and these may be some distance apart. Consider the two billabongs in the Roper River region in northern Australia called Yawurlwarda; one is near Roper Bar and the other, near Ngukurr (Baker 2002: 127). There are also two lakes, which are ecologically linked, ${ }^{28}$ near Cape Keerweer on Cape York Peninsula called by the Wik people Uthuk Eelen or Weenem Eelen 'Small Milky Way' or 'Small Lawyer Cane' and Uthuk Aweyn or Weenem Aweyn 'Big Milky Way' or 'Big Lawyer Cane' (Sutton 2002: 79). While the above examples are freshwater sites, there are also saltwater sites sharing a name. For example, the Bardi people in Western Australia call several reefs Mardaj (Bowern 2009: 323). However, these examples all involve billabongs, lakes or reefs sharing a name with other billabongs, lakes or reefs whereas the Meriam reefs Birig and Giau share their name with a landsite and fishtrap.

Since these Meriam places are named after ancestors, it is reasonable to conclude that the ancestors were involved in some kind of incident at each place, both on land and at sea. Scott and Mulrennan in their discussion about land tenure on Erub island, a neighbouring island closely connected to the Meriam people, found that the same creation myths connect outlying reefs and cays to the home island (1999: 155). The Meriam coreferential names for places on land and at sea suggest a similar case.

28 Peter Sutton (pers. comm.) 


\section{Grammatical structure}

Meriam placenames are grammatically nouns, nominal compounds or complex phrases.

They can be a common noun such as Bur 'Saltwater Mud', a personal name such as Karas or a nominalised verb such as Akesakes. These nouns can take nominal inflections. For example, in the following sentence, the placenames are suffixed with the locative inflection:

\section{(4) Ka nabakiamulu nazir atakrem} Burge/Karasge/Akesakesge.

I'm going to pick up trochus shell from Bur/Karas/Akesakes reefs.

$\begin{array}{lll}\text { ka } & \text { na-bakiamu-lu } & \text { nazir } \\ \text { 1.SG.S } & \text { FUT.1-go-FUT.1SG } & \text { trochus.O } \\ \begin{array}{l}\text { a-etaker-em } \\ \text { NOM-pick.up-ALL }\end{array} & \text { Bur/Karas/Akesakes-ge } & \end{array}$

Unlike Australian Aboriginal languages, there are no inflected verbs, verb phrases or headless relative clauses as placenames. Any verb which is part of a placename in Meriam, will be in a nominalised form. This is formed by dropping the first syllable in the verb and adding the prefix $a$-. For example, the reef Akesakes is derived from the nominalised form of the verb dikes.

Placenames can also be formed with a common noun or personal name plus a limited set of generic topographic terms (wésor 'sandcay or sandbar' is never used with placenames). Examples of compounds are: Sim Kep 'hibiscus+small. sunken.reef' or Gaidan Pasis 'ancestral name+passage (TSC)' or Op Nor 'ancestral name/front/face+reef.'

The grammatical structure of placenames with generic topographic terms varies. There are examples of placenames where the topographic feature has become incorporated into the name. For example, Aum Kep is a compound of an ancestral name and topographic term which is inflected as a single syntactic phrase:

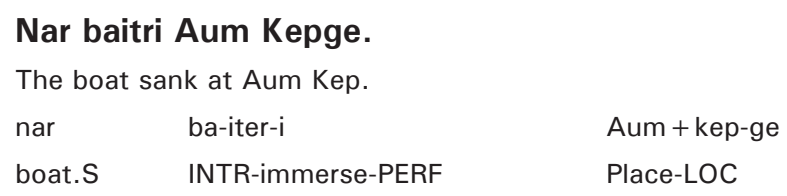

However, there are also examples where it is ambiguous as to whether the generic topographic term is part of the placename. For example, the reef Akesakes is inflected with or without the generic topographic feature: 
Indigenous and Minority Placenames

The boat sank at the reef Akesakes.

$\begin{array}{lll}\text { nar } & \text { ba-iter-i } & \text { Akesakes-ge } \\ \text { boat.S } & \text { INTR-immerse-PERF } & \text { Place-LOC }\end{array}$

(7) Wi emetu tabakomerti Akesakes Norlam.

They've returned from Akesakes reef.

wi emetu ta-ba-akomeret-i

3PL.S finish TO-PL.S-return-PERF

Akesakes + nor-lam

Place + reef-ABL

Further work is needed to determine their precise grammatical status.

Placenames can be adjectival phrases formed with a modifier and head noun. Two examples were given earlier: Adud Nor 'bad reef' and Au/Kebi Siar 'big/ little cod/personal name.' As there is a regular process for deriving modifiers from other parts of speech through reduplication, other adjectival phrases for placenames would include Tolitoli Nor 'tern+tern(adj) reef' and Akesakes Nor 'Broken up reef'. It may be that some of the common nouns used as placenames are reduced adjectival phrases.

Other types of complex nominal phrases for placenames are modifications of the grammatical types outlined above. Thus, there are placenames which are modified compounds: Garargarar Op Nor 'raised rocky platform(adj)+[front/ personal name+reef]' or Au/Kebi Bomi Nor 'big/little(adj)+[bomi (TSC)+reef]', or there are complex phrases which are compounds with an embedded adjectival phrase: Dingi New Pas 'dinghy(TSC)+[new(adj from Eng)+patch(TSC)].' Similarly, the alternative names for Madir and Marirar are compounds with embedded adjectival phrases: Mer Au Nor 'Mer+[big+reef]' or Sanba Au Nor 'sandbar(TSC)+[big + reef].'

The Meriam placename for Raine Island: Ebur bub werwer kaur, can either be analysed as a string of associative phrases with an embedded adjectival phrase:

bird-chest-[egg(adj)+island], or as a single associative phrase formed with a whole-part type compound and an embedded adjectival phrase: [bird+chest][egg(adj)+island].

\section{Conclusion}

This study has focussed on the linguistic content and semantic classification of Meriam saltwater placenames. Sources for semantic categories are ancestral, descriptive or physical and narrative. Taking into account alternative names and multiple associations with categories, the most common sources are ancestral (62 
per cent) and descriptive (55 per cent). The overall high proportion from these semantic domains reflects the very personal relationship that Meriam people have with their environment; these reefs are not only an integral part of their physical environment through travel, hunting and fishing but also a link to their ancestral past.

Comparisons with other Indigenous placename studies show remarkable similarities with a focus on the environment and its physical characteristics, connections to the flora and fauna, and mythological/ancestral associations. Furthermore, features from several categories are sometimes combined, such as landscape and mythology. However, there are major differences with the mythological/ancestral names. While the Australian Aboriginal placenames evoke an event associated with the mythological being, the Meriam and Marquesan placenames are named overtly after the personal name of an ancestor.

An interesting feature of some Meriam saltwater placenames is their shared name with a landsite or fishtrap. In some instances, the proximity of the two sites accounts for the same placename being used. In other cases, where these are distant, a possible explanation could be that the same ancestor was involved in events at both sites. It may also be suggestive of a close connection between land and sea in Meriam culture as put forth by Scott and Mulrennan (1999: 153).

Whether or not the same naming patterns can be found across the Torres Strait remains an open question. Maritime places listed in the statements from the two Erub claimants for the sea claim, George Mye and William (Bully) Saylor (September 2007) suggest similar patterns. However, it is essential that indigenous people's knowledge and information about their places be fully documented for future generations. The urgency of this task has been brought home to me by the death of two dear friends and contributors for this study, Atai and Usiam Wailu. 
Indigenous and Minority Placenames

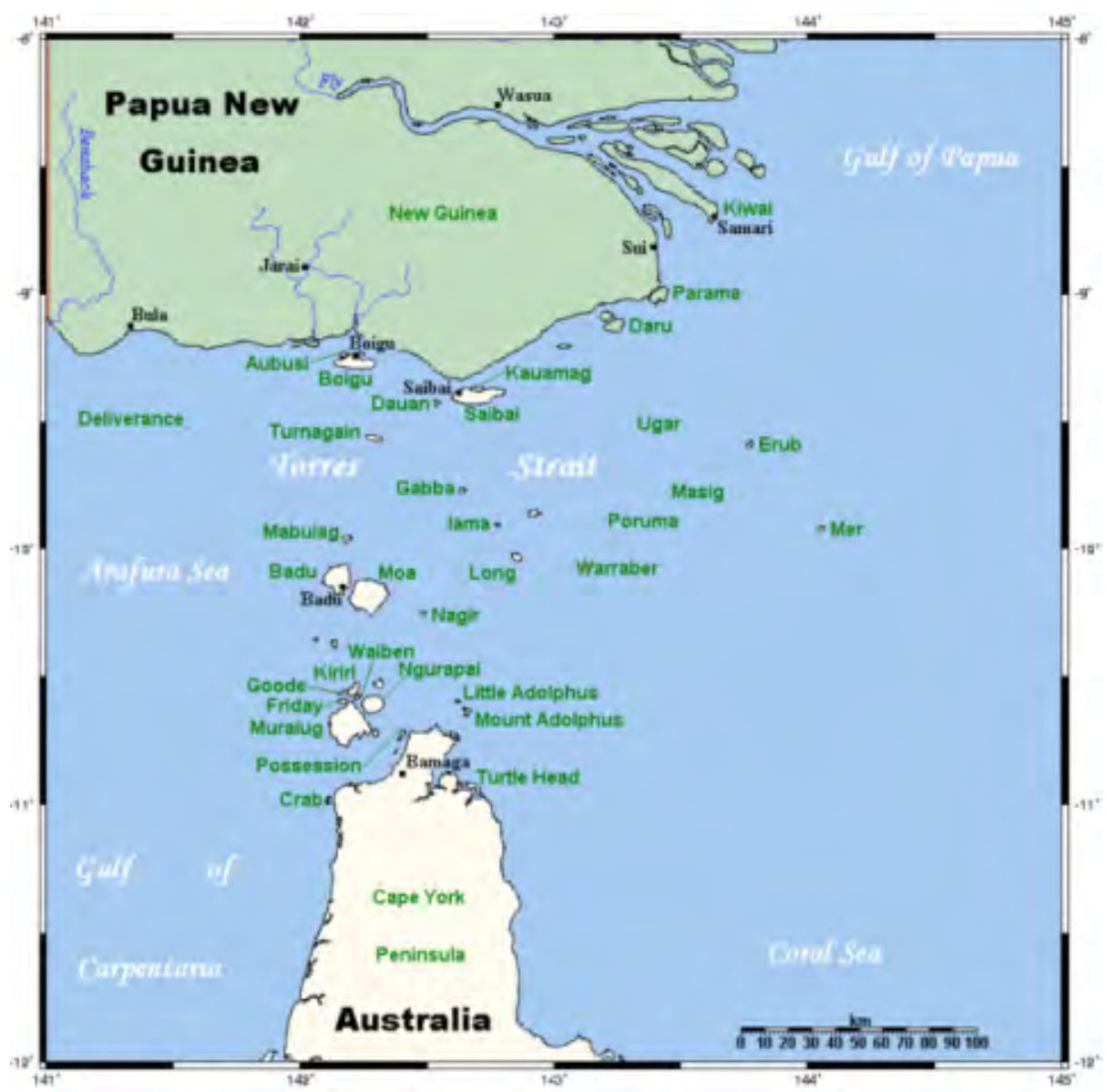

Map 1: Torres Strait.

Source: Torres Strait Island Regional Council. 
9. Saltwater Placenames around Mer in the Torres Strait

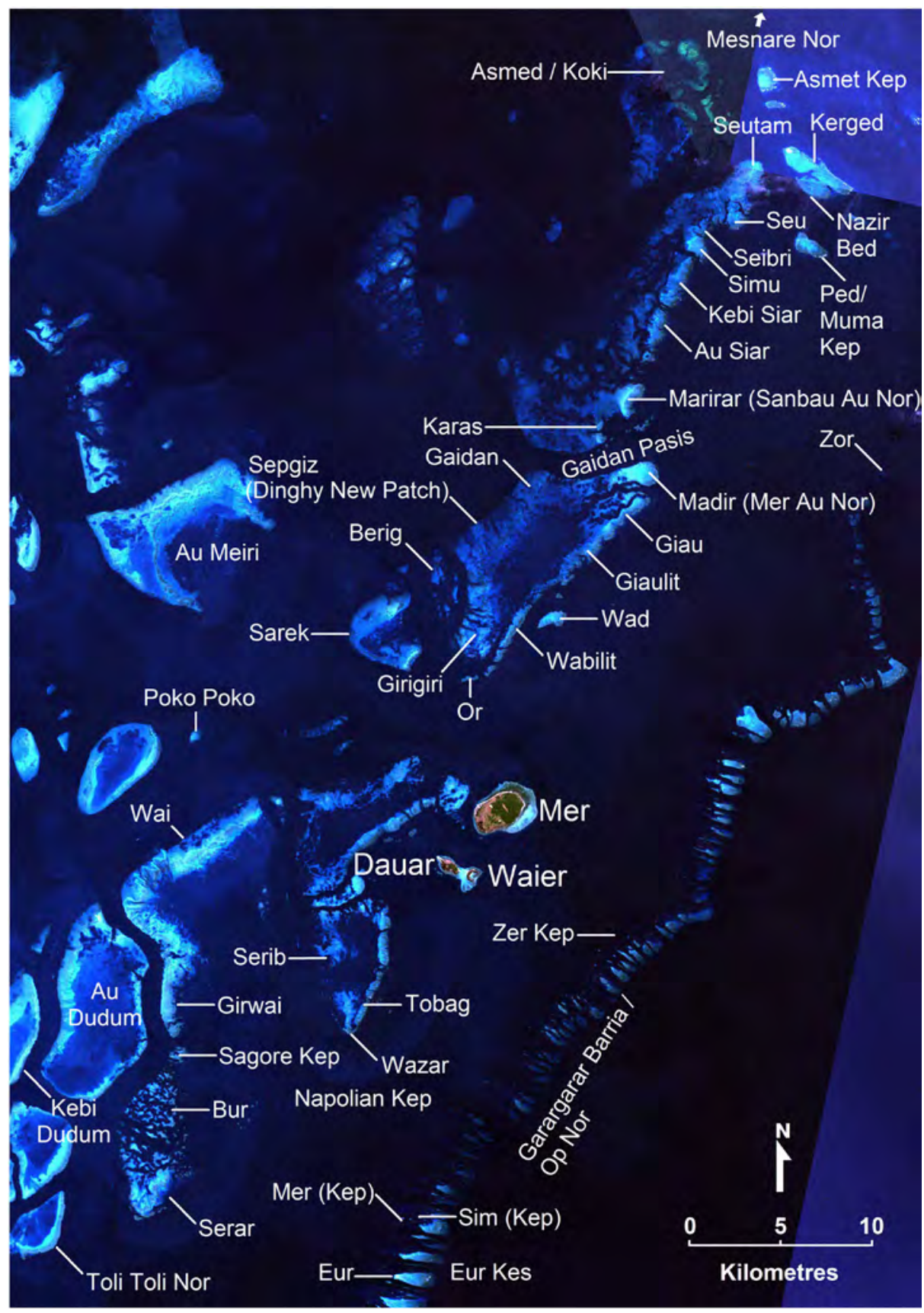

Map 2: Outer reefs for Mer, Dauar and Waier.

Source: Courtesy of Atai Wailu, Native Title Office, Torres Strait Regional Authority, 2008. 


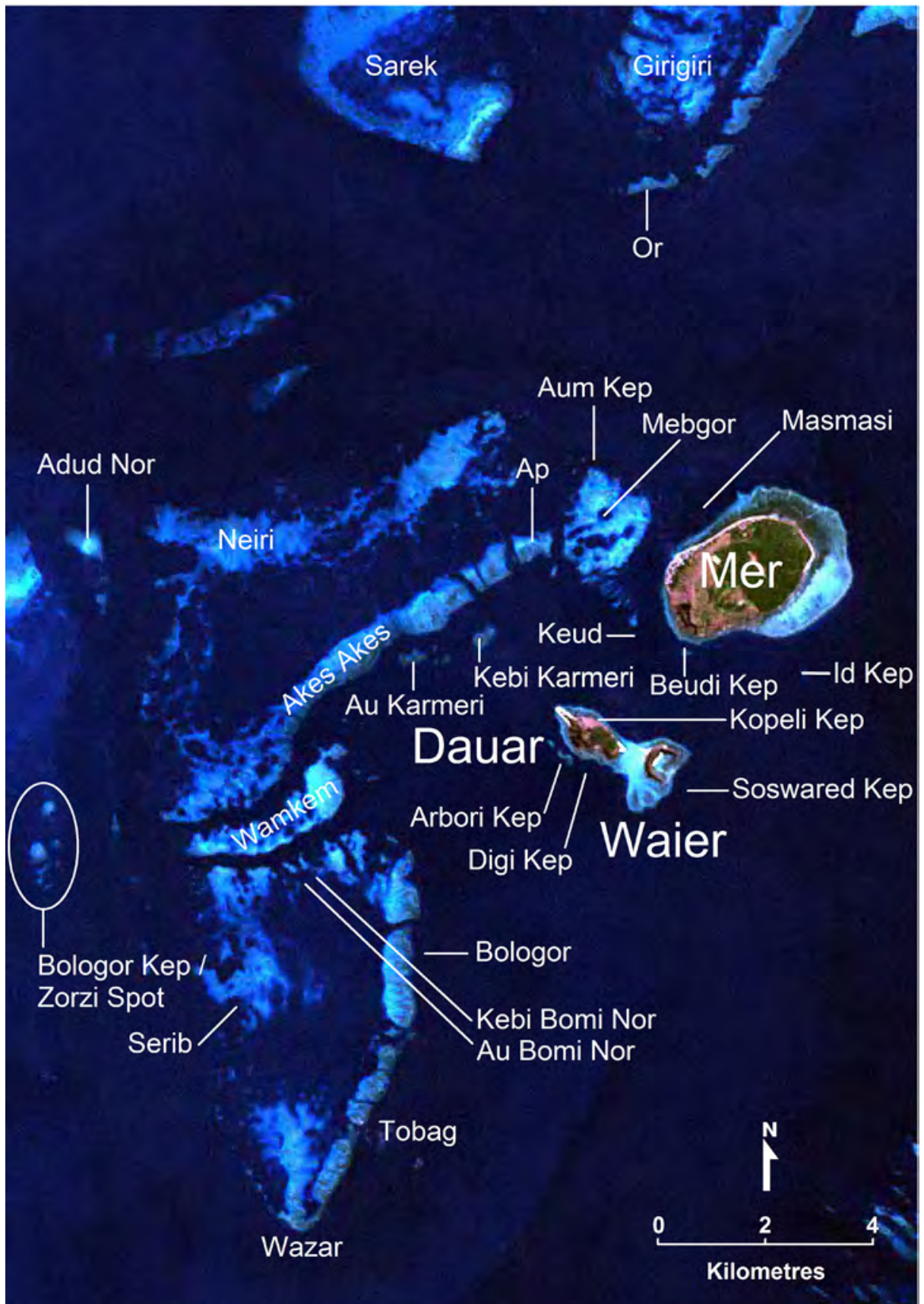

Map 3: Inner reefs for Mer, Dauar and Waier.

Source: Courtesy of Atai Wailu, Native Title Office, Torres Strait Regional Authority, 2008. 


\section{List of Placenames and Meanings}

$\begin{array}{ll}\text { nor } & \text { reef } \\ \text { kep } & \text { small, sunken reef } \\ \text { pasis } & \text { passage (TSC) } \\ \text { kes } & \text { passage }\end{array}$

To the north of Mer:

Asmet Kep

Bau Kep

Birig

Gaidan

Gaidan Pasis

Garboi

Giau

Giaulit

Girigiri

Karas

Kérged

Madir

Marirar

Meiri (Au/Kebi)

Mesnare Nor

Nazir Bed

Or

Ped

Sarek

Seibri

Sepgiz

Seu

Seutam
Ancestral name; also known as Asmed Kep

Unknown origin; possibly from the proper name Bau or the noun meaning 'seat'?

Ancestral name

Ancestral name

Ancestral name

Ancestral name (not on map)

Ancestral name; also known as Giawei, Gawei or Giawi

Ancestral/Descriptive name; literally:

Giau + handle; also known

Ancestral/Descriptive name; as Giaulet literally: bird of paradise

Ancestral name

Ancestral/Descriptive name; literally: ovary + place?

Ancestral/Descriptive name; also known as Mer Au Nor literally: Mer big reef

Ancestral/Descriptive name; also known as Sanba Au Nor literally: 'sandbar' (TSC) big reef; also known as Marir

Ancestral/Descriptive name; literally: big/little Meiri

Narrative name; literally: missionary reef; so called because the missionaries spent their first night there on their way to Erub

Historical/Descriptive name; literally: trochus shell and bed (TSC)

Ancestral name

Ancestral/Descriptive/Narrative name; literally: bald; also known as Muma(r) kep

Ancestral name

Ancestral/Descriptive name; literally: crocodile

Ancestral/Descriptive name; literally: earth + root; also known as Dingi New Pas literally: dinghy new 'patch' (TSC)

Ancestral name

Ancestral/Descriptive name; literally:

Seu + branch 
Siar (Au/Kebi)

Simu

Wabilit

Wad

Zor
Ancestral /Descriptive name; literally: big/little cod

Ancestral name; also known as Smu

Ancestral/Descriptive name; literally: Wabi + handle; also known as Wabilet

Ancestral name

Descriptive name; literally: pumice stone

Close to Mer, Dauar and Waier:

Akesakes

Ap

Arbori Kep

Beudu Kep

Digi Kep

Gebar

Id Kep

Karmeri (Au/Kebi)

Keud

Kopoli Kep

Lager Kep

Masmasi Kep

Mebgor

Sagore

Soswared Kep

To the southwest of Mer:

Adud Nor

Neiri

Pokopoko

Sam Karem
Aum Kep

Descriptive name; from the nominalised form of dikes 'broken into pieces'

Descriptive name; literally: Macaranga shrub Unknown origin; from the nominalised form of darborik 'throw' or darbor 'prominent'?

Ancestral name; also the name for the cloud that hangs directly above Mer

$?$

Narrative name; also known as Dingi Kep; named after a dinghy which sank there

? (not on map)

Unknown origin; also known as Ed Kep; the same name as the adjacent land site

Ancestral/Descriptive name; literally: big/little Karmeri

Ancestral name

Descriptive/Narrative name; literally: sea perch; also related to a secret event

Descriptive name; literally: vine (not on map) ?

Ancestral/Descriptive name; also known as Wewe Mebgor literally: sandy moon + saltwater? or sandy moon + slope

Ancestral name

Ancestral name

Descriptive name; literally: bad reef (not on map) Ancestral name

Descriptive name; literally: turtle's intestines

Ancestral name; literally: cassowary deep channel (not on map)

To the east of Mer:

Op Nor
Ancestral/Descriptive name; literally: front/face/ upper/outside 
To the south of Mer:

Bologor Kep (Au/Kebi) Descriptive/Narrative name; literally: big/little sawfish; also

Bomi Nor (Au/Kebi)

Bur

Dudum (Au/Kebi)

Eur (Kes)

Garargarar Op Nor

Girwai

Lim

Mer Kep

Napolan Kep

Pakor

Serar

Sirib

Sim Kep

Tobag

Tolitoli Nor

Tulit

Unui Ubi

Wai

Wamkem

Wazar

Zer Kep known as Zozi (George) spot because George mistook a diving bird for a shark

Unknown origin/Descriptive name; literally: big/ little bombora?

Descriptive name; literally: saltwater mud

Unknown origin/Descriptive name; literally: big/ little speed

Ancestral name

Descriptive name; literally: raised rocky platform front reef; a raised rocky area used by birds for rest and nesting

Descriptive name; literally: wild yam

Unknown origin; literally: sun (not on map)

Ancestral name

Narrative name; name of someone killed by sorcery

Descriptive name; literally: red bass (not on map)

Descriptive name; literally: tern

Descriptve name; literally: a type of vine

Ancestral/Descriptive name; literally: hibiscus tree

Ancestral name

Descriptive name; literally: sandpipers; also a landsite

Unknown origin/Descriptive; literally: Tu-handle (not on map)

? (not on map)

Ancestral/Descriptive name; literally: sprouting coconut

Unknown origin; related to bisiwam 'type of grass skirt'?; literally: grass skirt-with; connected to an incident with the Dauar women?

Descriptive name; related to the modern MM word zar 'the place where the fish go to hide'

Unknown origin; literally: banana skin

Not listed on the map and precise location unknown:

Edgor

Koki

Meme (Nor)

Werer

\section{?}

Ancestral name; literally: northwest wind

Ancestral name; also known as Meimei Nor

Unknown origin; literally: hunger 


\section{References}

Alpher, B. 2002, 'The archaism and linguistic connections of some Yir-Yoront tract-names', in The Land is a Map: Placenames of Indigenous Origin in Australia, L. Hercus, F. Hodges and J. Simpson (eds), Pandanus Books in association with Pacific Linguistics, Canberra: 131-139.

Alpher, B., G. O'Grady and C. Bowern 2008, 'Western Torres Strait language classification and development', in Morphology and Language History: In Honour of Harold Koch, C. Bowern, B. Evans and L. Miceli (eds), Benjamins, Amsterdam/Philadelphia: 15-30.

Baker, B. 2002, “'I'm going to where her brisket is": placenames in the Roper', in The Land is a Map: Placenames of Indigenous Origin in Australia, L. Hercus, F. Hodges and J. Simpson (eds), Pandanus Books in association with Pacific Linguistics, Canberra: 103-129.

Bowern, C. 2009, 'Naming Bardi places', in Aboriginal Placenames: Naming and Re-naming the Australian Landscape, L. Hercus and H. Koch (eds), ANU E Press and Aboriginal History Inc., Canberra: 327-346.

Cablitz, G. 2008, "When "what" is "where": a linguistic analysis of landscape terms, place names and body part terms in Marquesan (Oceanic, French Polynesia)', in Language and Landscape: A Cross-linguistic Perspective, N. Burenhult and S. Levinson (eds), Language Sciences 30: 200-226.

Henshaw, A. 2006, 'Pausing along the journey: learning landscapes, environmental change and toponymy amongst the Sikusilarmiut', Arctic Anthropology 43(1): 52-66.

Hercus, L. and J. Simpson 2002, 'Indigenous placenames: an introduction', in The Land is a Map: Placenames of Indigenous Origin in Australia, L. Hercus, F. Hodges and J. Simpson (eds), Pandanus Books in association with Pacific Linguistics, Canberra: 1-23.

Mye, G. 'Witness Statement', in Leo Akiba and George Mye on behalf of the Torres Strait Islanders of the Regional Seas Claim Area and the State of Queensland and others, Federal Court of Australia November 2001.

Saylor, W.H. 'Witness Statement', in Leo Akiba and George Mye on behalf of the Torres Strait Islanders of the Regional Seas Claim Area and the State of Queensland and others, Federal Court of Australia November 2001.

Scott, C. and M. Mulrennan 1999, 'Land and sea tenure at Erub', Oceania 70: 146-176. 
Shnukal, A. 1988, 'Broken, an introduction to the creole language of Torres Strait', Pacific Linguistics Series C(107).

Sutton, P. 2002, 'On the translatability of placenames in the Wik Region, Cape York Peninsula', in The Land is a Map: Placenames of Indigenous Origin in Australia, L. Hercus, F. Hodges and J. Simpson (eds), Pandanus Books in association with Pacific Linguistics, Canberra: 75-86.

Thornton, T. 1977, 'Anthropological studies of Native American place naming', American Indian Quarterly 21(2): 209-228.

Wailu, A. 'Witness Statement', in Leo Akiba and George Mye on behalf of the Torres Strait Islanders of the Regional Seas Claim Area and the State of Queensland and others, Federal Court of Australia November 2001. 
This text taken from Indigenous and Minority Placenames: Australian and International Perspectives, Edited by Ian D. Clark, Luise Hercus and Laura Kostanski, published 2014 by ANU Press, The Australian National University, Canberra, Australia. 